\title{
Deficits in Trace Cued Fear Conditioning in Galanin-Treated Rats and Galanin-Overexpressing Transgenic Mice
}

\author{
Jefferson W. Kinney, ${ }^{1}$ Grzegorz Starosta, Andrew Holmes, Craige C. Wrenn, \\ Rebecca J. Yang, Ashley P. Harris, Katharine C. Long, and Jacqueline N. Crawley \\ Section on Behavioral Genomics, National Institute of Mental Health, Bethesda, Maryland 20892, USA
}

\begin{abstract}
Galanin inhibits the release of several neurotransmitters and produces performance deficits in a variety of spatial and aversive learning and memory tasks. The experiments in this study investigated the role galanin has in emotional learning and memory using a standard delay cued and contextual fear conditioning task. Rats were administered galanin into the lateral ventricles before training, and scored for freezing behavior in the same context and in a novel context with and without an auditory cue (CS) that had been paired previously with an aversive stimulus (US). Galanin-overexpressing transgenic mice were tested in an identical behavioral protocol. The galanin-administered rats and the transgenic mice were not significantly different from their respective controls on this task. A more challenging trace cued and contextual fear conditioning procedure was administered to separate groups of galanin-treated rats and galanin-overexpressing transgenic mice. Subjects were trained with the same CS and US, however, a 2.5-sec delay was inserted between CS offset and US onset. Following the trace conditioning, rats administered galanin and mice overexpressing galanin both exhibited significantly less freezing to the CS in the novel context as compared with their control groups. These results indicate that the observed disruption of cued fear conditioning was specific to the more difficult trace conditioning task. These findings are the first demonstration that galanin impairs performance on an emotional memory task and support the hypothesis that galanin-induced deficits are specific to more difficult cognitive tasks.
\end{abstract}

Galanin is a neuropeptide expressed in the mammalian brain that inhibits the release of acetylcholine, glutamate, norepinephrine, and serotonin (Bartfai et al. 1993; Robinson et al. 1996; McDonald and Crawley 1997; Kinney et al. 1998; Wang et al. 1999; Branchek et al. 2000; Waters and Krause 2000; Wrenn and Crawley 2001). In addition, galanin has inhibitory actions on signal transduction mechanisms, including adenylate cyclase activity and phosphatidyl inositol hydrolysis (Palazzi et al. 1991; Karelson and Langel 1998; Iismaa and Shine 1999). Furthermore, galanin is overexpressed in the basal forebrain in Alzheimer's disease (AD) (Chan-Palay 1988; Beal et al. 1990; Mufson et al. 1993; Bowser et al. 1997). The role of galanin in AD neurodegeneration and dementia is under investigation.

When administered into the lateral ventricles or hippocampus of rats, galanin induces deficits in several cognitive tasks, including T-maze delayed alternation, delayed nonmatching to position, starburst radial maze, and the Morris water task (Sundstrom et al. 1988; Givens et al. 1992; Malin et al. 1992; Robinson and Crawley 1993a,b, 1994; Shandra

${ }^{1}$ Corresponding author.

E-MAIL kinneyj@intra.nimh.nih.gov; FAX (301) 480-1164. Article and publication are at http://www.learnmem.org/cgi/doi/ $10.1101 / \mathrm{m} .49502$. et al. 1994; Ukai et al. 1995; McDonald and Crawley 1996, 1997; Ögren et al. 1996; McDonald et al. 1997, 1998; Schött et al. 1998a,b, 2000; Stefani and Gold 1998; Gleason et al. 1999). Transgenic mice overexpressing galanin show performance deficits in spatial navigation on the Morris water task, and in an olfactory memory task, social transmission of food preference (Steiner et al. 2001). Fear conditioned emotional learning and memory tasks have not been investigated.

Learning and memory deficits observed following exogenous administration of galanin in the rat and in galaninoverexpressing transgenic mice appear to be selective impairments in performance on the more demanding explicit components of cognitive tasks (McDonald et al. 1998). Performance deficits following galanin administration appear primarily on difficult, hippocampally-dependent components of the tasks, for example, probe trial deficits in the Morris water task following normal hidden platform training (Gleason et al. 1999; Steiner et al. 2001). One hypothesis is that the inhibitory effect of galanin is detected only under cognitively demanding conditions, when full hippocampal neurotransmission is essential. To understand the type of task affected by galanin more fully, it is necessary to directly compare the actions of galanin in a simple versus a more complex version of a behavioral task. In addition, it is

LEARNING \& MEMORY 9:178-190 @ 2002 by Cold Spring Harbor Laboratory Press ISSN1072-0502/02 \$5.00

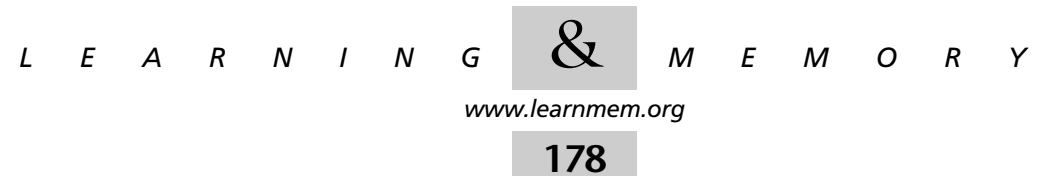


useful to compare the actions of galanin in hippocampal versus nonhippocampal-dependent tasks.

Delay cued and contextual fear conditioning (CCF) is a classically conditioned learning and memory task. Standard delay CCF consists of an initially neutral conditioned stimulus (CS), typically an auditory tone, being simultaneously presented with an unconditioned stimulus (US), typically a footshock. Following the pairing of the CS and US, subjects display freezing behavior when presented with the CS (cued fear), as well as when returned to the environment in which the US was presented (contextual fear). Both the hippocampus and the amygdala mediate components of fear conditioning, although controversy continues on their relative contributions to each component (Kim and Fanselow 1992; Phillips and LeDoux 1992, 1994; Paylor et al. 1994; Maren et al. 1996a; Logue et al. 1997; McNish et al. 1997; Anagnostaras et al. 1999; Antoniadis and McDonald 2000; Gewirtz et al. 2000; Schafe et al. 2001). The cued fear component requires an intact amygdala (LeDoux et al. 1990; Phillips and LeDoux 1992; Davis and Whalen 2001; Schafe et al. 2001). Lesion studies have shown that conditioned cued fear was intact following hippocampal lesion, but absent following amygdalar lesion (Phillips and LeDoux 1992). The contextual fear component appears to require an intact hippocampus, as shown in lesion and pharmacological studies (Phillips and LeDoux 1992; Chen et al. 1996; Logue et al. 1997; Holland and Bouton 1999; Young et al. 2000; Anagnostaras et al. 2001; Corcoran and Maren 2001; Wallenstein and Vago 2001). It has been hypothesized that the hippocampus mediates the association of the US and the constellation of cues in the environment during training (Phillips and LeDoux 1994; Nail-Boucherie et al. 2000; Hall et al. 2001). In addition, specific glutamate receptors within the amygdala also contribute to contextual fear conditioning (Fanselow and Kim 1994; Maren et al. 1996b; Rodrigues et al. 2001).

Trace CCF differs from the standard delay CCF in that it requires a temporal association between the stimuli. In trace CCF, the CS and US do not coincide but are separated by several seconds. Additional hippocampal involvement is thought to be required for the cued fear association with a time delay between the CS and US (Solomon et al. 1986; Huerta et al. 2000). Lesion studies demonstrate that the hippocampus is necessary for trace cued fear (Solomon et al. 1986; Moyer et al. 1990; Sutherland and McDonald 1990; McEchron et al. 1998, 2000; Weiss et al. 1999; Ryou et al. 2001).

Our experiments were designed to test the effects of galanin in a standard emotional learning and memory task, delay CCF. Furthermore, we tested the effects of galanin in the more challenging emotional learning and memory task, trace CCF. Two different model systems were employed: central galanin microinjections to normal rats and transgenic mice that overexpress galanin.
Day 1: Training

A

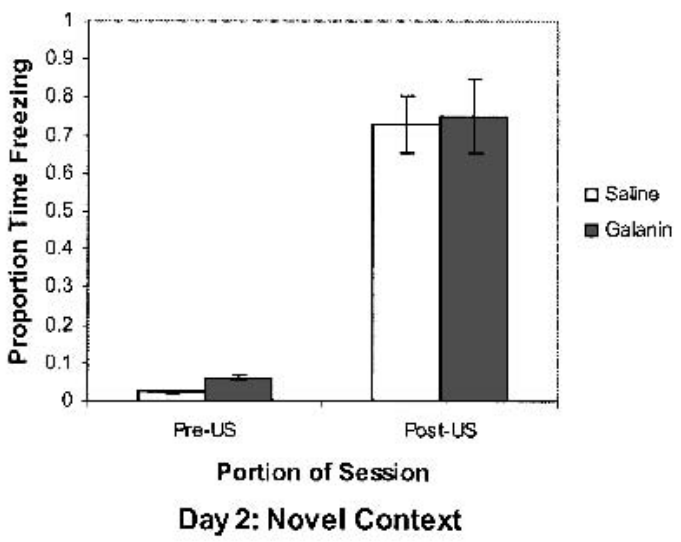

B

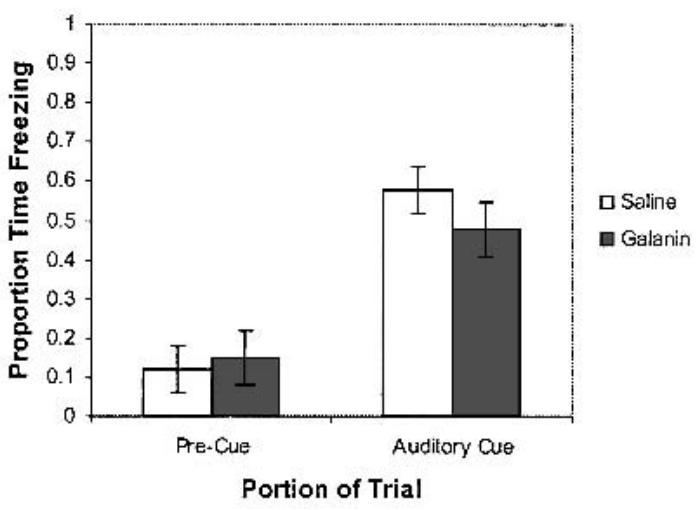

Day 3: Same Context

$C$

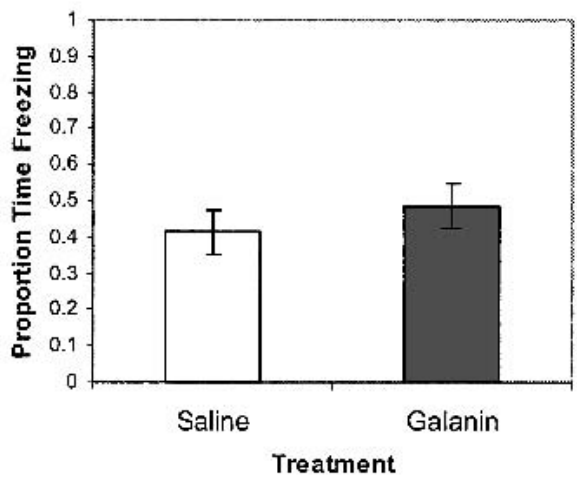

Figure 1 Delay cued and contextual fear conditioning—galanin vs. saline treated rats. Performance of Sprague-Dawley rats administered saline vehicle or galanin ( 3 nmoles) intraventricularly on the standard delay cued and contextual fear conditioning procedure. (A) Freezing behavior during the first 2 min of training before CS-US presentation (Pre-US), and the final 2 min of the training session after CS-US presentations (Post-US). (B) Freezing behavior in the novel context, $24 \mathrm{~h}$ after training, during the first $3 \mathrm{~min}$ of no CS presentation (Pre-Cue), and during the 3 min of CS presentation (Auditory Cue). (C) Freezing behavior $48 \mathrm{~h}$ after training, in the same context in which training was carried out on day 1 . Data are presented as means \pm SEM. No significant treatment differences were detected.

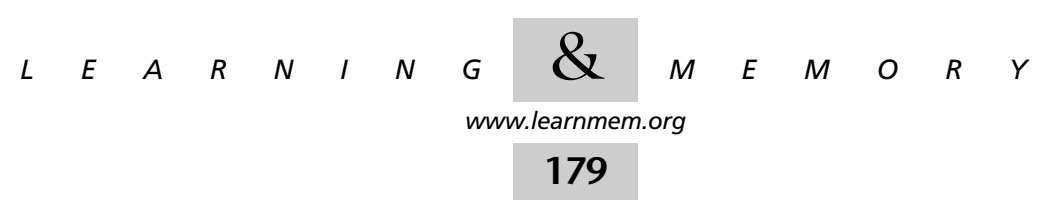




\section{RESULTS}

\section{Rats}

\section{Standard Delay CCF}

As shown in Figure 1, no significant differences were detected in the proportion of time spent freezing for the last 2 min of the day 1 training session between the rats administered intraventricular galanin versus saline $\left(\mathrm{F}_{(1,18)}=0.63\right.$; $P=.804)$. Similarly, galanin had no significant effect on

Day 1: Training

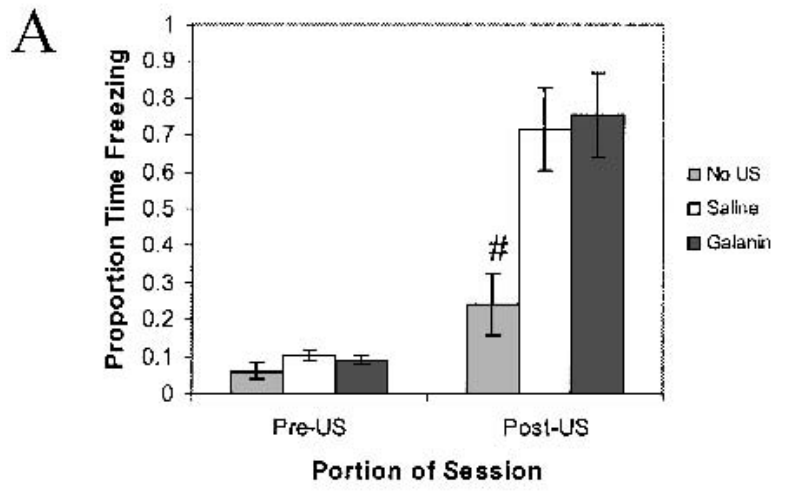

Day 2: Novel Context

B

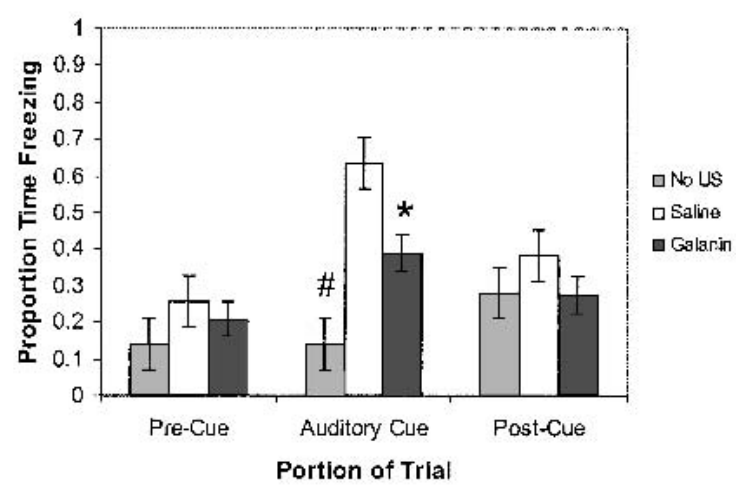

Day 3: Same Context

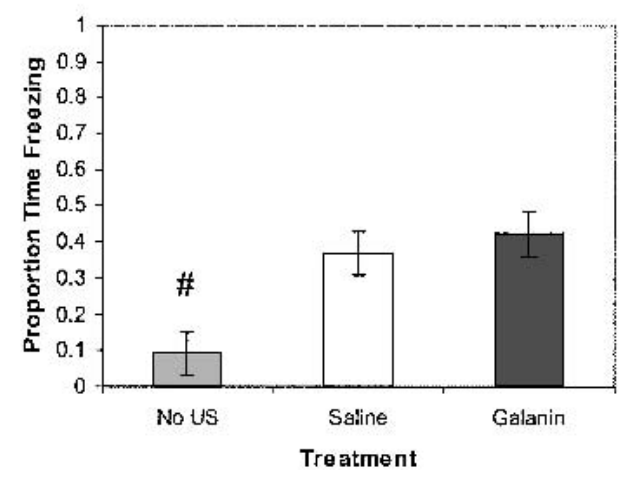

freezing in the day 2 novel context either before CS presentation $\left(\mathrm{F}_{(1,18)}=0.84 ; P=.371\right)$, or during CS presentation $\left(\mathrm{F}_{(1,18)}=1.21 ; P=.286\right)$. No significant differences were detected between the galanin-treated and salinetreated rats on day 3 contextual fear $\left(\mathrm{F}_{(1,18)}=1.02 ; P=\right.$ .326).

\section{Trace CCF}

As shown in Figure 2, a significant difference in the proportion of time spent freezing for the last $2 \mathrm{~min}$ of the training session was detected $\left(\mathrm{F}_{(2,31)}=20.983 ; P=.001\right)$. Tukey post-hoc comparisons revealed that galanin and saline treatment groups did not differ significantly $(P=.875)$, but controls with no US presentation froze significantly less than galanin-treated rats $(P=.001)$, and saline treated rats $(P=$ .001). There were no significant differences between any of the groups during the first $3 \mathrm{~min}$ in the novel context before the CS presentation $\left(\mathrm{F}_{(2,31)}=2.15 ; P=.134\right)$. The presentation of the CS in the novel context produced a significant difference between groups $\left(\mathrm{F}_{(2,31)}=23.409 ; P=.001\right)$. Tukey post-hoc comparisons revealed that galanin-treated rats froze significantly less than saline treated rats $(P=$ $.003)$. Controls with no US presentation froze significantly less than galanin- $(P=.007)$ or saline- $(P=.001)$ treated rats. No significant differences were observed between any of the treatment groups for the 90 sec following the cessation of the CS in the novel context $\left(\mathrm{F}_{(2,31)}=.890 ; P=.421\right)$. Lastly, a significant difference between groups was observed $48 \mathrm{~h}$ after training, in the proportion of time spent freezing when subjects were returned to the training environment for the contextual fear test $\left(\mathrm{F}_{(2,31)}=11.215 ; P=\right.$ .001). Tukey post-hoc comparisons detected significantly less freezing in the controls with no US presentation versus both the galanin- $(P=.001)$ and saline- $(P=.002)$ treated groups that were presented with the US.

\section{Histology}

Of 54 cannulated rats, two displayed incorrect placements. In both cases, the ventral tip of the cannula was dorsal to

Figure 2 Trace cued and contextual fear conditioning-galanin vs. saline treated rats. Performance of Sprague-Dawley rats administered saline or galanin ( 3 nmoles) intraventricularly on the trace cued and contextual fear conditioning procedure. $(A)$ Freezing behavior during the first 2 min of training before CS-US presentation (Pre-US), and the final 2 min of the training session after CS-US presentations (Post-US). (B) Freezing behavior in the novel context, $24 \mathrm{~h}$ after training during the first $3 \mathrm{~min}$ of no CS presentation (Pre Cue), $3 \mathrm{~min}$ of CS presentation (Auditory Cue), and $1.5 \mathrm{~min}$ following offset of CS (Post Cue). (C) Freezing behavior $48 \mathrm{~h}$ after training, in the same context in which training was carried out on day 1 . Rats receiving no US were employed as controls (No US), to confirm the ability of the US to induce significant freezing in the saline and galanin treatment groups. Galanin reduced freezing to the auditory cue in the trace fear conditioning task. Data are presented as means $\pm \mathrm{SEM},\left({ }^{*}\right) P=.003$ galanin-treated rats versus saline-treated rats. (\#) $P \leq .01$ for No US controls versus saline and galanin treatments.

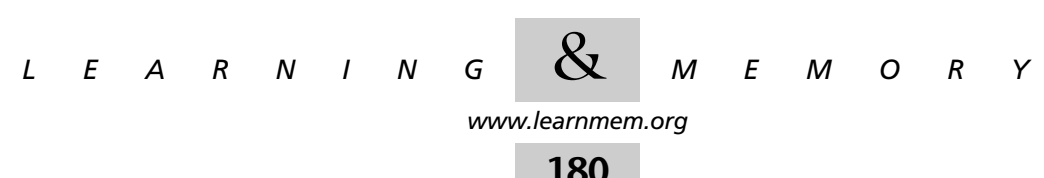




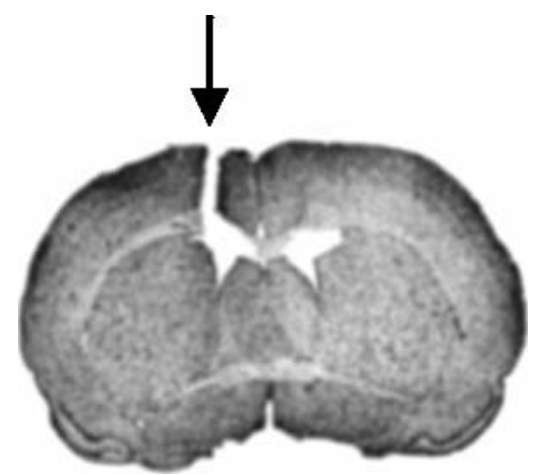

Figure 3 Representative cannula placement in the lateral ventricle of microinjected rats. Arrow indicates cannula track terminating within the lateral ventricle.

the ventricle. Data from these subjects were removed from the behavioral analysis. The correct placement of the can- nula in 52 rats is illustrated by a representative section in Figure 3 .

\section{Mice}

Table 1 presents the measures of general health, sensory abilities, and motor functions. No significant differences were detected between these GAL-tg mice and their wildtype littermate controls, confirming previous findings from other batches of GAL-tg and wild-type mice (Steiner et al. 2001; Holmes et al. 2002).

Figure 4 shows that GAL-tg mice were not significantly different from wild-type controls on exploratory horizontal locomotion in the open field $\left(\mathrm{F}_{(1,61)}=.109 ; P=.742\right)$, accelerating rotarod $\left(\mathrm{F}_{(1,61)}=.031 ; P=.862\right)$, hot plate $(t=$ $-0.0541 ; d f=56 ; P=0.957)$ tail flick $(t=-1.128 ; d f=61$; $P=0.264)$, and acoustic startle $\left(\mathrm{F}_{(1,61)}=.856 ; P=.359\right)$ tests.

Table 1. Summary of Results from the Multi-tiered Behavioral Observations of Wild-type (WT) Littermate Controls and Galanin Overexpressing Transgenic Mice (GAL-tg)

\begin{tabular}{|c|c|c|c|c|}
\hline & \multicolumn{2}{|c|}{ Females } & \multicolumn{2}{|c|}{ Males } \\
\hline & WT (8) & GAL-tg (21) & WT (11) & GAL-tg (23) \\
\hline \multicolumn{5}{|l|}{ General health } \\
\hline Body weight (g) & $19.77 \pm 4.2$ & $21.22 \pm 3.4$ & $26.99 \pm 3.7$ & $25.1 \pm 3.1$ \\
\hline Poor coat condition & 13 & 18 & 0 & 0 \\
\hline Missing whiskers & 14 & 0 & 0 & 4 \\
\hline Piloerection & 0 & 0 & 0 & 0 \\
\hline Unusual body tone & 14 & 5 & 10 & 0 \\
\hline Unusual limb tone & 0 & 0 & 10 & 8 \\
\hline \multicolumn{5}{|l|}{ Home cage behaviors } \\
\hline Solitary sleeping & 0 & 0 & 0 & 0 \\
\hline Fighting and aggression & 0 & 0 & 0 & 4 \\
\hline \multicolumn{5}{|l|}{ Motoric, muscular abilities } \\
\hline Positional passivity & 0 & 0 & 0 & 8 \\
\hline Trunk curl & 100 & 100 & 100 & 100 \\
\hline Forepaw reaching & 100 & 100 & 100 & 100 \\
\hline Righting reflex & 100 & 100 & 100 & 100 \\
\hline Wire hang (seconds to fall) & $56.4 \pm 3.2$ & $58.4 \pm 4.4$ & $49.3 \pm 3.8$ & $57.8 \pm 3.8$ \\
\hline \multicolumn{5}{|l|}{ Reflexes } \\
\hline Eye blink & 100 & 100 & 100 & 100 \\
\hline Ear twitch & 100 & 100 & 100 & 100 \\
\hline Whisker response & 86 & 95 & 100 & 100 \\
\hline Toe pinch response & 100 & 100 & 100 & 100 \\
\hline \multicolumn{5}{|l|}{ Reactivity } \\
\hline Moving away on petting & 100 & 100 & 100 & 100 \\
\hline Struggle on restraint & 100 & 100 & 100 & 100 \\
\hline Vocalization on restraint & 57 & 65 & 50 & 58 \\
\hline Dowel biting (3 point scale) & 1.8 & 2.0 & 2.0 & 1.9 \\
\hline \multicolumn{5}{|l|}{ Empty cage behaviors } \\
\hline Freezing on transfer & 0 & 0 & 0 & 0 \\
\hline Wild running & 0 & 0 & 0 & 0 \\
\hline Stereotypies & 0 & 0 & 0 & 0 \\
\hline Cage exploration (3 point scale) & 2.4 & 2.2 & 2.1 & 2.2 \\
\hline Grooming (3 point scale) & 1.6 & 1.5 & 1.8 & 1.7 \\
\hline
\end{tabular}

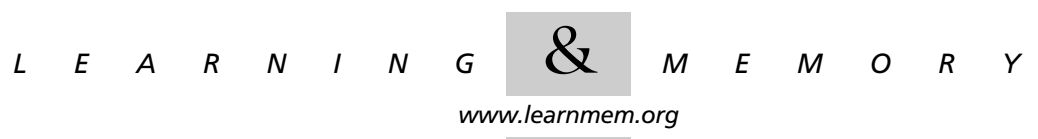


Open Field

A

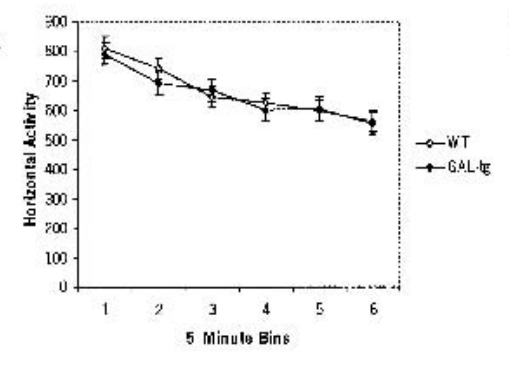

C

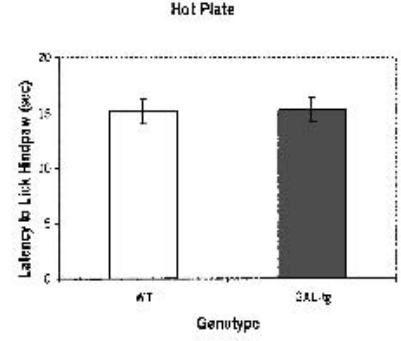

Accuterating Rotarod
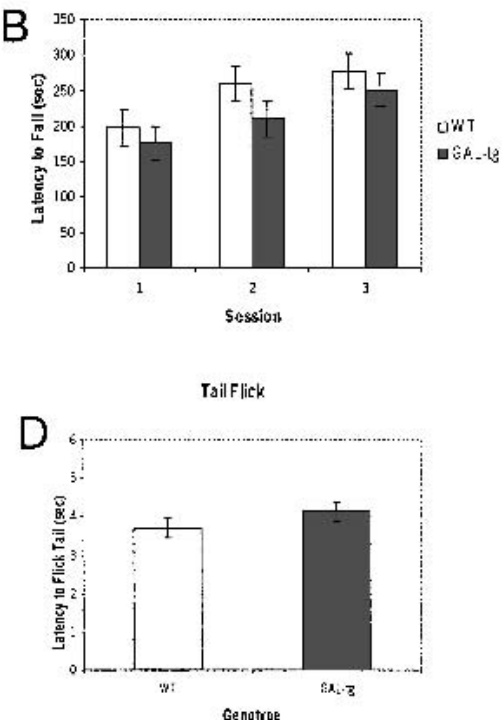

Acoustic Startle

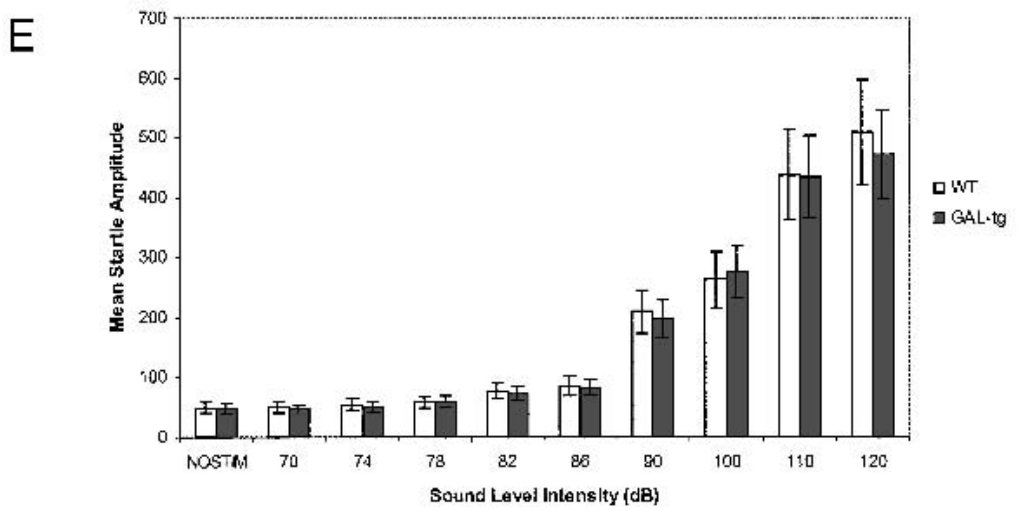

Figure 4 Sensory abilities and motor functions in wild-type littermate controls and galanin-overexpressing transgenic mice (GAL-tg) mice. Tasks chosen were relevant to the procedural requirements of cued and contextual fear conditioning. Data represent $(A)$ exploratory activity in an automated open field; $(B)$ motor coordination and balance on an accelerating rotarod; $(C)$ hot plate analgesia; $(D)$ tail flick analgesia; and $(E)$ auditory threshold measured by acoustic startle. GAL-tg mice did not differ significantly from wild-type littermate controls on these tasks. Data are presented as means \pm SEM.

\section{Standard Delay CCF}

As shown in Figure 5, GAL-tg and wild-type controls were not significantly different in the proportion of time spent freezing following the CS-US pairing $\left(\mathrm{F}_{(1,41)}=.076 ; P=\right.$ .784). Similarly, no significant differences were detected between the GAL-tg mice and wild-type controls in freezing behavior on day 2 in the novel context in the absence of the $\mathrm{CS}\left(\mathrm{F}_{(1,41)}=.001 ; P=.992\right)$, nor when the CS was presented $\left(\mathrm{F}_{(1,41)}=.013 ; P=.911\right)$. Proportion of time spent freezing when the mice were returned on day 3 to the same context in which training took place was not significantly different across genotypes $\left(\mathrm{F}_{(1,41)}=.283 ; P=.598\right)$.

\section{Trace CCF}

As shown in Figure 6, comparisons between genotypes on training day 1 in trace $\mathrm{CCF}$ revealed a significant difference between groups $\left(\mathrm{F}_{(2,70)}=14.243 ; P=.001\right)$. Tukey post-hoc comparisons revealed that the GAL-tg group was not significantly different from the wild-type controls $(P=.788)$, but the controls with no US presentation differed significantly from the GAL-tg $(P=$ $.001)$, and wild-type mice $(P=.001)$. There were no significant differences between groups on day 2 in the novel context before the presentation of the $\mathrm{CS}\left(\mathrm{F}_{(2,70)}=2.448 ; P\right.$ $=.094)$. In the novel context the presentation of the CS produced a significant difference between groups of mice $\left(\mathrm{F}_{(2,70)}=\right.$ $17.11 ; P=.001)$. Tukey post-hoc comparisons revealed significantly less freezing in GAL-tg mice as compared with wild-type controls $(P=.003)$. The control group with no US presentation froze significantly less than both the GAL-tg $(P=.001)$ and the wild-type controls $(P=.001)$. No significant difference was detected between any of the groups in the $90 \mathrm{sec}$ following the cessation of the $\mathrm{CS}$ in the novel environment $\left(\mathrm{F}_{(2,70)}=\right.$ $2.731 ; P=.072$ ). Finally, a significant difference was detected in contextual freezing on day $3\left(\mathrm{~F}_{(2,70)}=4.214 ; P=.019\right)$. Tukey posthoc comparisons revealed that GAL-tg and wild-type controls were not significantly different $(P=.786)$, but controls with no US presentation froze significantly less than both GAL-tg $(P=.009)$, and wild-type $(P=$ .014).

Figure 7 shows the data from the second experiment, repeating the trace $\mathrm{CCF}$ test in a separate cohort of GAL-tg and wildtype mice. As in experiment 1, a significant difference was detected between the GALtg mice and wild-type controls in the novel context when the CS was presented $\left(\mathrm{F}_{(1,50)}=7.045 ; P=\right.$ .011). Again, no other significant differences between genotypes were detected in experiment 2 , thereby replicating the findings of experiment 1.

\section{DISCUSSION}

A growing body of literature has demonstrated that galanin administered centrally to rats induces performance deficits in a variety of learning and memory tasks (Robinson and Crawley 1993b; Ukai et al. 1995; McDonald and Crawley 1997; McDonald et al. 1998; Ögren et al. 1996; Schött et al. 2000; Wrenn and Crawley 2001). Our findings further sup-

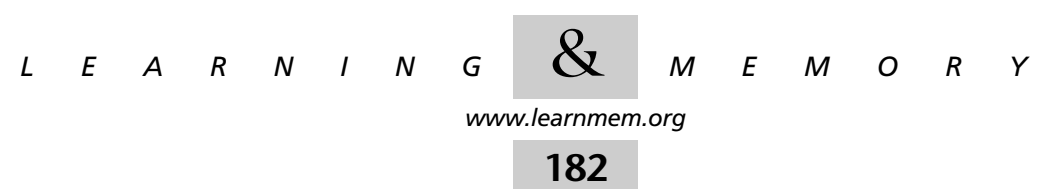


A

B

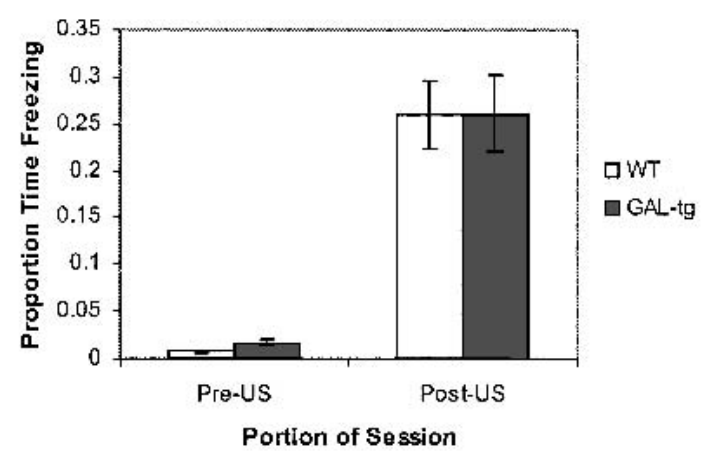

C

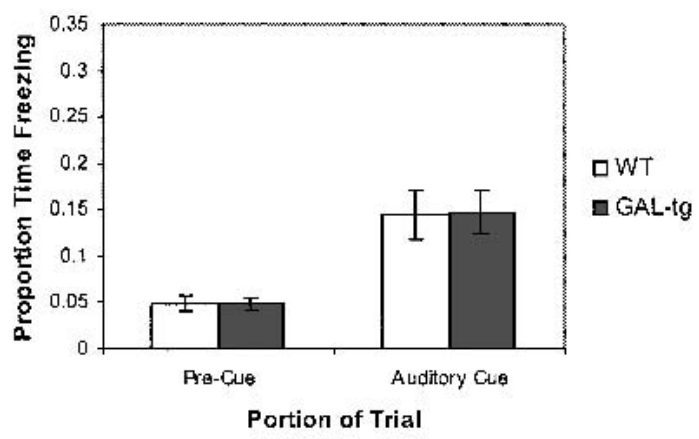

Day 3: Same Context

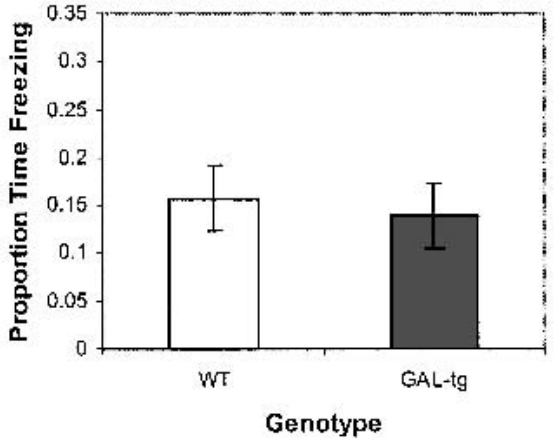

Figure 5 Delay cued and contextual fear conditioning-galaninoverexpressing transgenic mice. Performance of wild-type littermates (WT) and galanin-overexpressing transgenic mice (GAL-tg) in the standard delay cued and contextual fear conditioning experiment. $(A)$ Freezing behavior during the first 2 min of training before CS-US presentation (Pre-US), and the final $2 \mathrm{~min}$ of the training session after CS-US presentations (Post-US). (B) Freezing behavior in the novel context $24 \mathrm{~h}$ after training, during the first 3 min of no CS presentation (Pre-Cue) and during the 3 min of CS presentation (Auditory Cue). (C) Freezing behavior $48 \mathrm{~h}$ following training, in the same context in which training was carried out on day 1 . Data are presented as means \pm SEM. No significant differences between genotypes were detected. port an inhibitory role of galanin on cognitive processes. Both intraventricular administration of galanin to rats and overexpression of galanin in transgenic mice produced a deficit in an emotional learning and memory task. Although galanin did not affect any component of standard delay fear conditioning, galanin impaired performance on trace fear conditioning, a more challenging variant of delay CCF that requires hippocampal mediation of both cued and contextual fear (Moyer et al. 1990; Sutherland and McDonald 1990; Weiss et al. 1999; Huerta et al. 2000; McEchron et al. 2000; Ryou et al. 2001). Furthermore, galanin specifically reduced freezing on the cued components of trace fear conditioning. Cued freezing in the trace fear conditioning test is thought to depend on the integrity of both the amygdala and the hippocampus (LeDoux et al. 1990; Moyer et al. 1990; Sutherland and McDonald 1990; Phillips and LeDoux 1992; McEchron et al. 1998, 2000, 2001; Weiss et al. 1999; Davis and Whalen 2001; Ryou et al. 2001; Schafe et al. 2001). Specifically, both the galanin administered rats, and the galanin-overexpressing transgenic mice exhibited a deficit only in the particular aspect of the conditioning procedure that requires both amygdala and hippocampal mediation to a single discrete stimulus (trace cued fear). These findings indicate that the cognitive impairments produced by galanin are consistent across two species, and across exogenous and endogenous manipulations, on specific components of fear conditioning.

The addition of a delay between the CS and US has been used in a variety of investigations of hippocampal learning and memory (McEchron et al. 1998, 2001; Weiss et al. 1999; Huerta et al. 2000; Ryou et al. 2001). Delays ranging from $0.5 \mathrm{sec}$ to $>30 \mathrm{sec}$ have been employed. The use of a 2.5-sec delay in this study was selected as the minimum delay in this task that has been demonstrated to disrupt performance (Huerta et al. 2000). It would be interesting to further examine the effects of galanin on the trace CCF procedure using longer delays between the CS and US to determine if increasing the length of the delay between stimuli produces even larger differences in freezing attributable to galanin.

The GAL-tg mice were similar to wild-type controls on measures of general health, neurological reflexes, sensory, and motor capabilities. Therefore, the GAL-tg mutation had no physical consequences on motor functions that could influence freezing behavior, on hearing necessary for detecting the auditory $\mathrm{CS}$, or on pain perception necessary to respond to the US. Furthermore, replication of the deficit in trace cued freezing in two independent batches of GAL-tg emphasizes the robustness of the selective cognitive phenotype.

Our data support the interpretation that galanin impairs performance on an emotional learning and memory task. Furthermore, these data provide support for an interpretation that the inhibitory actions of galanin are detect-

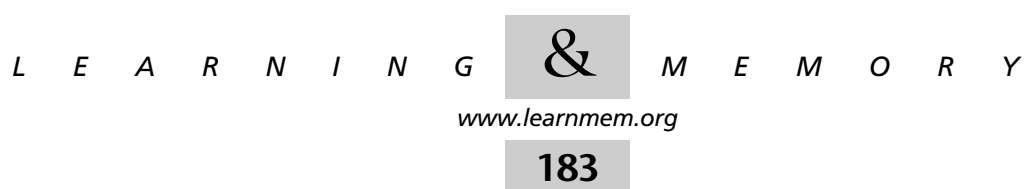


A

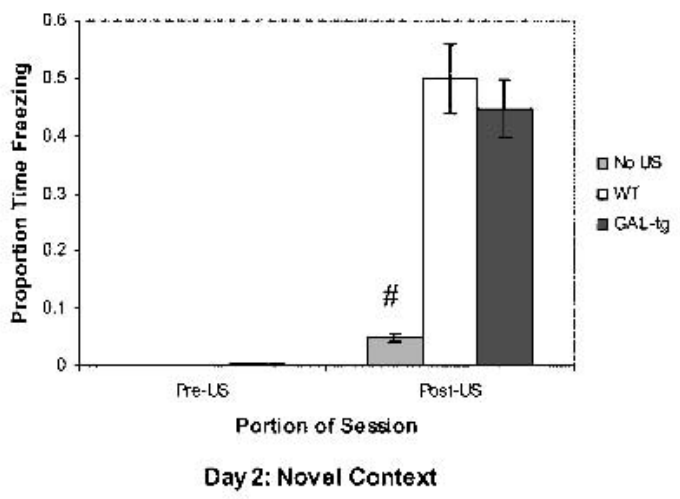

B

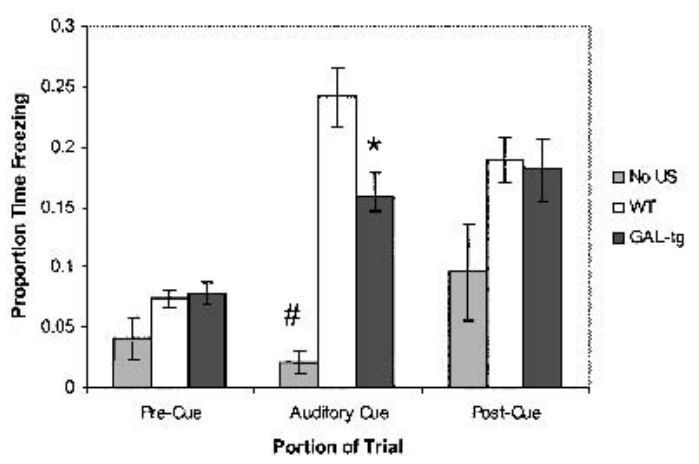

$\mathrm{C}$

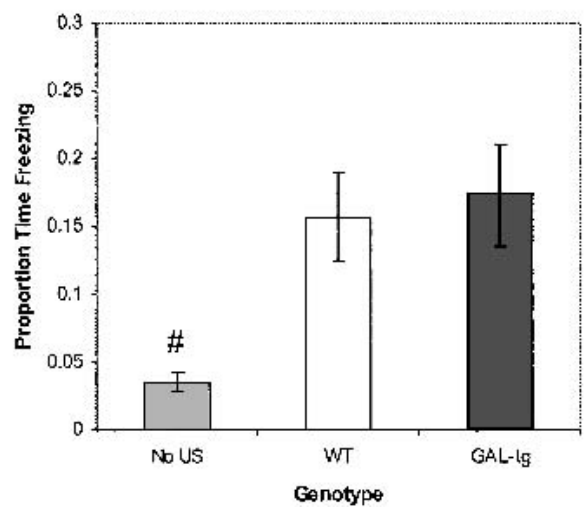

Figure 6 Trace cued and contextual fear conditioning-galaninoverexpressing transgenic mice: experiment 1. Performance of control C57BL/6J mice never presented with the US (No US), wildtype littermates (WT), and galanin-overexpressing transgenic (GALtg) mice in the trace cued and contextual fear conditioning experiment. (A) Freezing behavior during the first 2 min of the training before CS-US presentation (Pre US), and the final 2 min of training following CS-US presentations (Post US). (B) Freezing behavior in the novel context, $24 \mathrm{~h}$ after training, during the first $3 \mathrm{~min}$ of no CS presentation (Pre Cue), 3 min of CS presentation (Auditory Cue), and $1.5 \mathrm{~min}$ following offset of the CS (Post Cue). (C) Freezing behavior $48 \mathrm{~h}$ after training, in the same context in which training was carried out on day 1. GAL-tg mice displayed significantly less freezing to the auditory cue in the trace fear conditioning task. Data are presented as means $\pm \mathrm{SEM},\left({ }^{*}\right) P=.003$, GAL-tg versus WT. (\#) $P \leq .01$ for No US controls versus GAL-tg and wild type. able only when the task is sufficiently difficult. The insertion of a delay between the CS and US in trace CCF has been argued to require greater hippocampal involvement (Solomon et al. 1986; Moyer et al. 1990; Sutherland and McDonald 1990; Huerta et al. 2000; McEchron et al. 2000) than delayed cued fear. Phillips and LeDoux (1992) demonstrated that animals with hippocampal lesions exhibit normal cued fear in standard delay CCF training procedures, indicating an association of the CS and the US. Lesions of the hippocampus, however, severely disrupt cued fear conditioning in the trace CCF procedure (McEchron et al. 1998; Weiss et al. 1999; McEchron et al. 2001; Ryou et al. 2001). In our experiments, we hypothesize that the temporal separation of the CS and the US in trace conditioning makes the association of the CS and US more difficult than in standard delay conditioning. This hypothesis is supported by evidence that trace conditioning requires additional training trials compared with standard delay conditioning (for review, see Beylin et al. 2001). A second rationale for trace CCF being more difficult, as well as a potential explanation of the deficit in trace cued fear without a deficit in contextual fear, is that trace cued fear represents the only measure of hippocampal- and amygdala-mediated conditioning to a single stimulus (CS). In delay contextual fear, the animal may learn an association between the footshock and multiple cues present in the training environment. In trace cued fear, however, the subject must exhibit the conditioned fear to a single stimulus presented during training (CS) rather than to the constellation of cues in the training environment (contextual fear). Furthermore, the cued fear association must be made when a temporal separation (trace interval) separates the CS and US. No such temporal separation exists between the contextual cues in the training room and the presentation of the US.

The nature of peptide release indicates a mechanism by which galanin-induced cognitive deficits might depend on the difficulty of the task. In neurons containing co-existing classical neurotransmitters and neuropeptides, much higher neuronal firing rates or bursts of activity are required to release the peptide than to release the classical transmitter (Hökfelt et al. 1987; Consolo et al. 1994; Muschol and Salzberg 2000). Inhibitory actions of endogenous galanin in galanin-overexpressing transgenic mice may occur only during behavioral conditions in which a sufficiently high degree of neuronal activity is occurring in galanin-containing pathways to evoke the release of galanin. For example, in delay CCF, Maren (2000) demonstrated a CS-elicited spike of activity in the lateral amygdala on presentation of the CS after it has been paired with a US. It seems likely that the hippocampally-dependent association of the CS and US in trace CCF may similarly induce a spike of activity within the hippocampus, of sufficient magnitude and duration to release endogenous galanin.

In addition, the actions of endogenously overexpressed

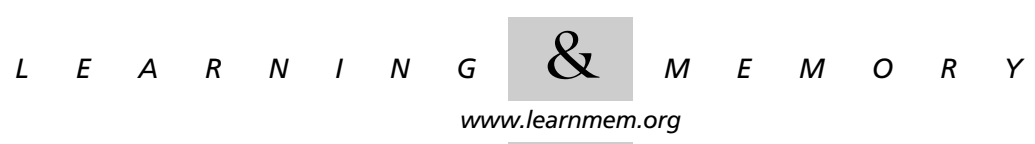


Day 1: Training

A

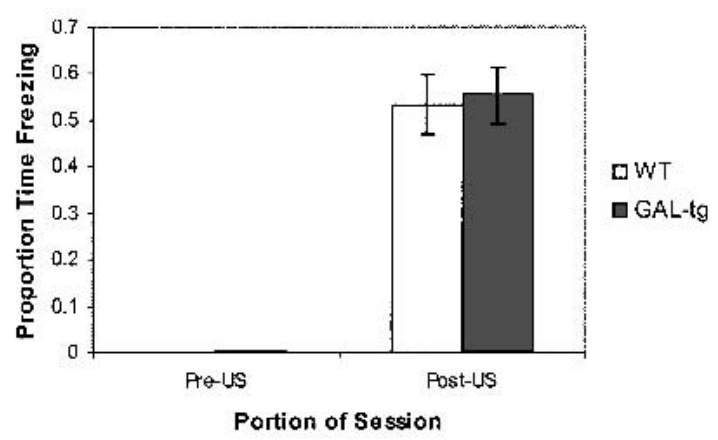

Day 2: Novel Context

B

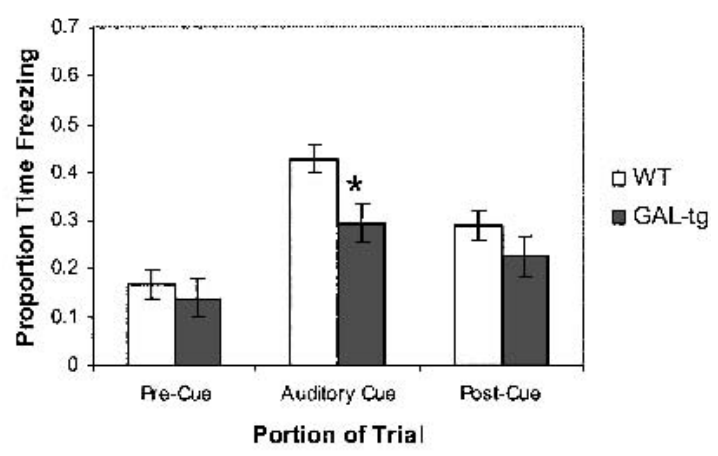

Day 3: Same Context

C

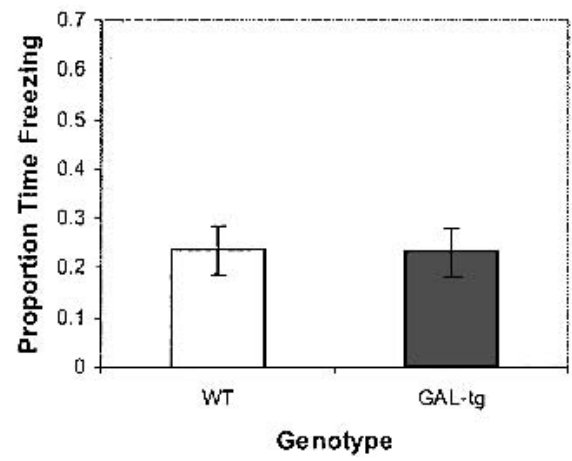

Figure 7 Trace cued and contextual fear conditioning—galaninoverexpressing transgenic mice: experiment 2. Performance of an independent group of wild-type littermates (WT), and galanin-overexpressing transgenic (GAL-tg) mice in a second trace cued and contextual fear conditioning experiment $(A)$ Freezing behavior during the first $2 \mathrm{~min}$ of the training before CS-US presentation (Pre US), and the final 2 min of training following CS-US presentations (Post US). (B) Freezing behavior in the novel context, $24 \mathrm{~h}$ after training, during the first 3 min of no CS presentation (Pre Cue), 3 min of CS presentation (Auditory Cue), and $1.5 \mathrm{~min}$ following offset of the CS (Post Cue). (C) Freezing behavior $48 \mathrm{~h}$ after training, in the same context in which training was carried out on day 1. GAL-tg mice displayed significantly less freezing to the auditory cue in the trace fear conditioning task. Experiment 2 replicated the results of experiment 1 , shown in Fig. 6 . Data are presented as means \pm SEM, $\left.{ }^{*}\right) P=.011$, GAL-tg versus wild type. and exogenously administered galanin may be neuromodulatory, and therefore detectable only in tasks in which full hippocampal neurotransmission is required. Galanin inhibits the evoked release of acetylcholine, glutamate, norepinephrine, and serotonin in rat hippocampus (Zini et al. 1993; Robinson et al. 1996; Kinney et al. 1998; Mazarati et al. 2000), all of which have been implicated in learning and memory. In addition, galanin attenuates PI hydrolysis and adenylate cyclase activity in the hippocampus (Palazzi et al. 1991; Karelson and Langel 1998; Iismaa and Shine 1999), which have been demonstrated to be involved in hippocampally-mediated plasticity (Pontzer et al. 1990; Weisskopf et al. 1994; Wu et al. 1995; Xia et al. 1995; Fitzjohn et al. 1998; Villacres et al. 1998; Baker et al. 1999). Negligible neuromodulatory inhibition of neurotransmitter release or signal transduction mechanisms may occur when neurons are firing at low rates, e.g., during a more simple task, such as standard delay CCF. During performance of a more difficult task, however, such as trace CCF, a higher degree of neuronal activity, neurotransmission, and signal transduction may be required. A modest galanin-induced reduction in glutamate or acetylcholine release, or galanin-induced inhibition of intracellular mechanisms, may be sufficient to impair performance when full neuronal activity is required, such as learning the association between the CS and US when they do not coincide, as in trace CCF. Furthermore, galanin appears to act as an inhibitory modulator, particularly reducing the evoked release of neurotransmitters and the activity of signal transduction mechanisms in the hippocampus (Palazzi et al. 1991; Ögren et al. 1996; Robinson et al. 1996; Karelson and Langel 1998; Kinney et al. 1998). Modulatory inhibition produced by galanin may differ from hippocampal lesions in functional outcome. Therefore, galanin overexpression did not mimic the ability of hippocampal lesions to impair contextual fear in the present experiments.

The present findings in rodents support the emerging hypothesis that the cognitive impairments that characterize $\mathrm{AD}$ may be attributable, in part, to the inhibitory actions of galanin (Hökfelt et al. 1987; McDonald and Crawley 1997; Steiner et al. 2001). Overexpressed galaninergic fibers and terminals surround the basal forebrain cholinergic neurons that degenerate early in the disease progression (Chan-Palay 1988; Beal et al. 1990; Mufson et al. 1993; Bowser et al. 1997). It is interesting to speculate that neuronal damage within the basal forebrain caused by $\beta$-amyloid accumulation may represent the trigger for increased expression of galanin. Galanin and $\beta$-amyloid have been shown to synergistically inhibit acetylcholine release (Wang et al. 1999). These data indicate that inhibitory actions of overexpressed galanin on other neurotransmitters and second messengers may exacerbate the cognitive decline associated with $\mathrm{AD}$ pathology.

In conclusion, a disassociation between standard delay

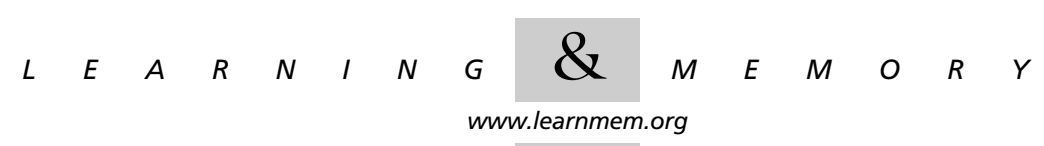


fear conditioning and trace fear conditioning was found in both rats administered galanin intraventricularly and transgenic mice overexpressing galanin. The results demonstrate that galanin produces deficits in cued freezing in the trace conditioning task, whereas it spares performance in the less demanding standard delay conditioning task. Inhibitory modulation by galanin of neurotransmission and/or intracellular signaling may represent the underlying mechanisms by which galanin impairs performance on more difficult learning and memory tasks.

\section{MATERIALS AND METHODS}

\section{Subjects}

All procedures were conducted in accordance with the National Institutes of Health (NIH) guidelines for the care and use of laboratory animals, and approved by the National Institute of Mental Health (NIMH) Animal Care and Use Committee.

\section{Rats}

A total of 54 adult male Sprague-Dawley rats (Taconic) were $\sim 100$ days-old on arrival. Rats were individually housed in a vivarium maintained at a constant temperature of $22^{\circ} \mathrm{C}$ on a 12-h light-dark cycle (0800 light onset), with continuous access to rat chow and water in the home cages. Behavioral tests were conducted during the light cycle, between the hours of 10 am and $4 \mathrm{pm}$.

Rats were unilaterally implanted with $1.4 \mathrm{~cm}, 24$ gauge stainless steel guide cannulae (Small Parts Inc.) into the right lateral ventricle, under ketamine/xylaxine anesthesia. Following a midline incision, the scalp was exposed and the cannula was placed $1.0 \mathrm{~mm}$ lateral, $0.5 \mathrm{~mm}$ posterior, and $3.5 \mathrm{~mm}$ ventral from bregma (Paxinos and Watson 1986). The guide cannula was secured to the skull with dental acrylic and stainless steel screws. Rats were then administered an analgesic (Ketoprofen) to minimize post-operative pain. Recovery for a minimum of $8 \mathrm{~d}$ was allowed before behavioral experiments were initiated. Injections were administered on the training day, $5 \mathrm{~min}$ before the start of the session for both the standard and trace CCF procedures. No treatments were given on test days 2 or 3 . Injections were performed using a $1.5-\mathrm{cm}, 28-$ gauge injector inserted into the guide cannula, fabricated from hypodermic stainless steel tubing (Small Parts Inc.). Rats were injected with either $0.9 \% \mathrm{NaCl}$ vehicle at a volume of $3 \mu \mathrm{L}$, or 3 nmoles galanin $/ 3 \mu \mathrm{L}$ saline. The administration of either saline or galanin was carried out over $15 \mathrm{sec}(1 \mu \mathrm{L} / 5 \mathrm{sec})$, followed by an additional $45 \mathrm{sec}$ to allow the injection volume to distribute within the ventricle before removal of the injector. Rat galanin 1-29 was purchased from American Peptide Company.

\section{Mice}

Galanin-overexpressing transgenic mice (GAL-tg) and wild-type littermate controls (WT) were bred at The Jackson Laboratory. As described previously (Steiner et al. 2001), the galanin transgene was linked to a dopamine $\beta$-hydroxylase promoter. Genotyping did not distinguish homozygous from heterozygous GAL-tg. The transgenic line was backcrossed for seven generations into a C57BL/6J background. Heterozygote matings produced the cohorts of experimental mice. Galanin mRNA overexpression in GAL-tg was elevated approximately fivefold in the locus coeruleus; galanin peptide levels were approximately doubled in the forebrain, as compared to wild type (Steiner et al. 2001). Forty-four littermates were used for the standard delay cued and CCF: 12 male wild type, 12 male GAL-tg, 10 female wild type, and 10 female GAL-tg. A separate set of 63 littermates was used for the first trace cued and contextual fear conditioning experiment (trace CCF): 11 male wild type, 23 male GAL-tg, eight female wild type, and 21 female GAL-tg. The second trace CCF experiment employed an independent third set of 23 wild-type and 28 GAL-tg littermate females. An additional 10 normal male $\mathrm{C} 57 \mathrm{BL} / 6 \mathrm{~J}$ mice were used as nonshocked controls to quantitate baseline activity in the trace CCF experiments. All subjects were group-housed by gender. In a few cases, an animal was individually housed after repeated episodes of aggression toward or overgrooming of its cage-mates. Mice were housed in a vivarium maintained at a constant temperature of $22^{\circ} \mathrm{C}$ and maintained on a 12-h light-dark cycle (0600 light onset), with continuous access to mouse chow and water in the home cages.

\section{Multitiered Behavioral Screen}

Mice were first individually evaluated on measures of body weight, temperature, coat condition, missing whiskers, piloerection, forepaw reaching, and body/limb tone, as described previously (Crawley and Paylor 1997; Paylor et al. 1998; Holmes et al. 2002; Steiner et al. 2001). Neurological reflexes tested included trunk curl, righting reflex, positional passivity, ear twitch, toe pinch, whisker response, and corneal response. Home cage behaviors were scored for occurrence of solitary sleeping, nest building, aggression, and fighting. Mice were observed for $3 \mathrm{~min}$ in a novel cage for occurrence of exploration, wild running, stereotypes, freezing, and grooming.

Following the initial evaluation, mice were then tested on measures of sensory and motor abilities. Motor tasks consisted of the accelerating rotarod and open field locomotion. Sensory tasks included hotplate and tail flick analgesia, acoustic startle, and prepulse inhibition. Methods were as described previously (Crawley and Paylor 1997; Paylor et al. 1998; Holmes et al. 2002; Steiner et al. 2001).

\section{Standard Delay Cued Contextual Fear Conditioning}

Methods followed were similar to the established literature for this task (Chen et al. 1996; Wehner et al. 1997; Impey et al. 1998). The chamber used for fear conditioning and scoring of freezing to context was a $26 \mathrm{~cm} \times 23 \mathrm{~cm} \times 17 \mathrm{~cm}$ clear Plexiglas box with a metal grid floor for footshock delivery (Freeze Monitor, San Diego Instruments, San Diego, CA). The novel chamber for scoring of novel context and auditory cued fear was a triangular box, $50 \mathrm{~cm} \times 35.5$ $\mathrm{cm} \times 25 \mathrm{~cm}$, constructed of white plastic. Vanilla extract $(\sim 0.5 \mathrm{~mL}$; McCormick) was painted onto one of the walls of the novel chamber. A Dell Optiplex computer interfaced to a shock stimulator and speaker delivered the tone (CS) and shock (US). The tone generated by the speaker was $80 \mathrm{~dB}$ at a frequency of $810 \mathrm{~Hz}$. The shock was $0.5 \mathrm{~mA} \mathrm{AC}$ current, for $1.0 \mathrm{sec}$ for rats, and $0.2 \mathrm{~mA} \mathrm{AC}$ current for $1.0 \mathrm{sec}$ for mice. All procedures were carried out using San Diego Instruments software.

Rats were randomly assigned to either the saline group $(N=$ $10)$ or the galanin group $(N=10)$. The observer was blind to the treatment condition of the rats and to the genotype of the mice. The procedures used for both rats and mice were identical, with the exception that rats were given a central injection of either saline $(3 \mu \mathrm{L})$ or galanin $(3 \mathrm{nmole} / 3 \mu \mathrm{L}) 5 \mathrm{~min}$ before placement in the conditioning apparatus on day 1 . Figure $8 \mathrm{~A}$ describes the procedural components of standard delay CCF. On the training day,

\section{$\begin{array}{lllllllllllllll}\text { Lww.learnmem.org } & & & & & & & & & \end{array}$}


A) Standard Delay
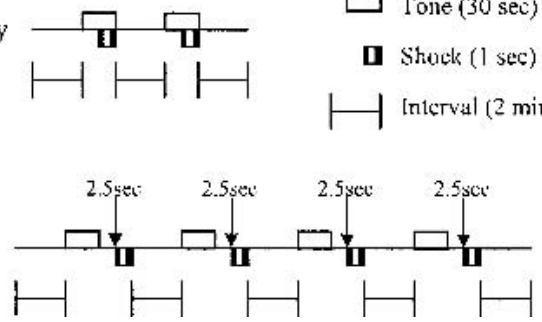

B) Trace

Figure 8 Cued and contextual fear training procedure. Schematic representation of the training protocol for standard delay cued and contextual fear conditioning and for trace cued and contextual fear conditioning. (A) Standard delay. Subjects were exposed to two 30 -sec presentations of the tone (CS) separated by $2.0 \mathrm{~min}$. The footshock (US) was presented for the final $1.0 \mathrm{sec}$ of the tone presentation. (B) Trace. Subjects were given four pairings of CS and US, with the presentation of the US beginning $2.5 \mathrm{sec}$ after CS offset.

the subject was placed into the conditioning chamber and given 2 min to explore the chamber. The CS tone was then presented for $30 \mathrm{sec}$. During the last second of the CS tone the US footshock was administered. The first CS and US pairing coterminated $2 \mathrm{~min}$ and 30 sec after the start of the session. The subject was then given 2 min to explore the chamber with no CS or US present. The CS was then presented again for $30 \mathrm{sec}$, with the US again presented during the last second of the tone presentation. Following the second CS-US pairing, the animals were allowed to explore the cage for 2 additional min. All subjects were then removed from the training chamber and returned to their home cage. Throughout the entire session the experimenter observed the animal every $10 \mathrm{sec}$ to score the presence or absence of freezing. Freezing behavior was defined as the absence of any movement with the exception of breathing (Kim and Fanselow 1992; Wehner et al. 1997). The data collected for the training session consisted of the proportion of observations in which the subject was scored as freezing during the first $2 \mathrm{~min}$ of the session (pretraining baseline freezing) and the proportion of observations in which the subject was scored as freezing during the last $2 \mathrm{~min}$ of the session (post-training measure). After each subject completed the training session, the chamber was cleaned with ethanol.

Twenty-four hours after training, subjects were individually removed from their home cages and taken to a different room for the auditory cued fear test. Each subject was placed in the triangular box (novel context) for $6 \mathrm{~min}$. The first $3 \mathrm{~min}$ consisted of baseline exploration in the absence of the CS. The CS tone used previously in training was then initiated for $3 \mathrm{~min}$. Presence or absence of freezing behavior was scored at 10-sec intervals for the entire 6-min session. At the end of the $3 \mathrm{~min}$ of CS presentation, the subjects were immediately returned to their home cage. After each subject completed the test session, the chamber was cleaned with ethanol.

Forty-eight hours after training, subjects were individually removed from their home cages and taken to the original training room for the contextual fear test. Each subject was placed into the same Freeze Monitor chamber in which training took place. Freezing behavior was scored at 10 -sec intervals over a 5 -min session. All conditions in the room were identical to the training day with the exception that the CS and US were not presented. After each subject completed the test session, the chamber was cleaned with ethanol.

\section{Trace Cued Contextual Fear Conditioning (Trace CCF)}

All procedures used for the trace CCF procedure were identical to standard delay CCF procedure, with the exception of US onset and number of CS and US pairings, as described previously (Crestani et al. 1999; Huerta et al. 2000). As shown in Figure 8B, a delay of 2.5 sec was inserted between the CS and US. In addition, subjects in the trace conditioning procedure received a total of four sequential CS and US pairings. Ten rats were administered saline vehicle and 10 rats were administered galanin $5 \mathrm{~min}$ before the start of training. Subjects were trained on day 1 in the Freeze Monitor environment. Following the training session, subjects were returned to their home cages. The auditory cued fear test sessions on day 2 were identical to those used in the standard cued fear experiment, with the exception of the duration of the session. Subjects were allowed to explore the novel environment for 3 min without CS presentation, followed by $3 \mathrm{~min}$ of continuous CS presentation. Following the termination of the CS, the subjects were allowed to explore the novel context for an additional $90 \mathrm{sec}$ to determine if the subjects learned that the tone signaled an upcoming shock in the trace procedure. Freezing behavior was scored at 10 -sec intervals throughout the entire session $(7.5 \mathrm{~min})$. The procedure for the trace contextual fear test on day 3 was identical to the procedure for the standard CCF test on day 3.

A control experiment was conducted to examine potential differences in the proportion of time spent freezing because of the added time and number of CS presentations necessary for training in the trace procedure. Ten saline-treated rats and 10 normal C57BL/6J male mice were exposed to the entire trace conditioning procedure, however, no US footshock was presented in the training session. All other procedures for these control groups were identical to subjects in the trace conditioning groups. These controls were used to establish whether the additional time in the trace training session resulted in increased habituation and freezing in any phase of the experiment.

\section{Histological Analysis}

Rats were euthanized via $\mathrm{CO}_{2}$ asphyxiation, and the brains were immediately removed and placed in an $8 \%$ formaldehyde solution. Tissue was sectioned at a thickness of $60 \mu \mathrm{m}$, mounted on gelatincoated slides, and stained with $0.1 \%$ thionen. Sections were examined under a stereoscopic light microscope to verify cannula placement. A rat that did not display a clear cannula track into the lateral ventricle was scored as a "miss" and the behavioral data of those subjects were removed from the data analysis.

\section{Statistical Analysis}

All data were analyzed using the SPSS statistical software package. Data collected on the initial behavioral observations were analyzed via $t$-tests (hot plate and tail flick), Repeated Measures Analysis of Variance (ANOVA) (rotarod and open field), or Analysis of Variance (all remaining data from neurological screen of general health, sensory abilities, and motor functions). Standard delay CCF and trace CCF data from rats were analyzed by one-way Analysis of Variance for each session, with Tukey post-hoc comparisons following a significant ANOVA. Standard delay CCF and trace CCF data from mice were analyzed by two-way ANOVA for gender and genotype. No significant differences were obtained because of gender. Data were therefore collapsed and analyzed by one-way ANOVA. Tukey post-hoc comparisons were used following a significant ANOVA.

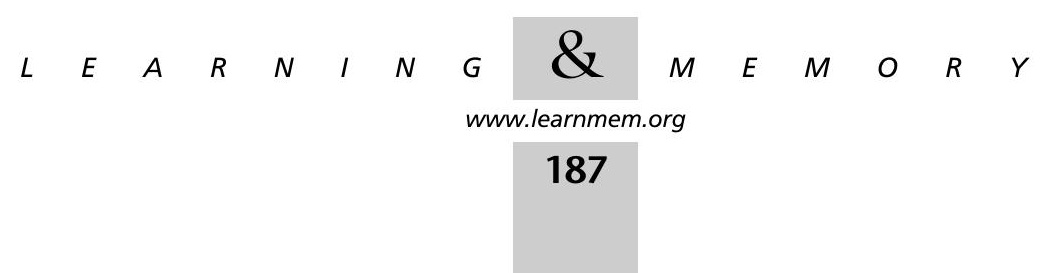




\section{ACKNOWLEDGMENTS}

The authors thank John Hohmann and Robert Steiner, University of Washington, for providing progenitor mice. This project was supported by the National Institute of Mental Health Intramural Research Program.

The publication costs of this article were defrayed in part by payment of page charges. This article must therefore be hereby marked "advertisement" in accordance with 18 USC section 1734 solely to indicate this fact.

\section{REFERENCES}

Anagnostaras, S.G., Maren, S., and Fanselow, M.S. 1999. Temporally graded retrograde amnesia of contextual fear after hippocampal damage in rats: Within-subjects examination. J. Neurosci. 19: 1106-1114.

Anagnostaras, S.G., Gale, G.D., and Fanselow, M.S. 2001. Hippocampus and contextual fear conditioning: Recent controversies and advances. Hippocampus 11: 8-17.

Antoniadis, E.A. and McDonald, R.J. 2000. Amygdala, hippocampus and discriminative fear conditioning to context. Behav. Brain Res. 108: 1-19.

Baker, L.P., Nielsen, M.D., Impey, S., Hacker, B.M., Poser, S.W., Chan, M.Y., and Storm, D.R. 1999. Regulation and immunohistochemical localization of $\beta \gamma$-stimulated adenylyl cyclases in mouse hippocampus. J. Neurosci. 19: 180-192.

Bartfai, T., Hökfelt, T., and Langel, Ü. 1993. Galanin - a neuroendocrine peptide. Crit. Rev. Neurobiol. 7: 229-274

Beal, M.F., MacGarvey, U., and Swartz, K.J. 1990. Galanin immunoreactivity is increased in the nucleus basalis of Meynert in Alzheimer's disease. Ann. Neurol. 28: 157-161.

Beylin, A.V., Gandhi, C.C., Wood, G.E., Talk, A.C., Matzel, L.D., and Shors, T.J. 2001. The role of the hippocampus in trace conditioning: Temporal discontinuity or task difficulty. Neurobiol. Learn. Memory 76: 447-461.

Bowser, R., Kordower, J.H., and Mufson, E.J. 1997. A confocal microscopic analysis of galaninergic hyperinnervation of cholinergic basal forebrain neurons in Alzheimer's disease. Brain Patbol. 7: 723-730.

Branchek, T.A., Smith, K.E., Gerald, C., and Walker, M.W. 2000. Galanin receptor subtypes. Trends Pharmacol. Sci. 21: 109-117.

Chan-Palay, V. 1988. Galanin hyperinnervates surviving neurons of the human basal nucleus of Meynert in dementias of Alzheimer's and Parkinson's disease: A hypothesis for the role of galanin in accentuating cholinergic dysfunction in dementia. J. Comp. Neurol. 273: 543-557.

Chen, C., Tonegawa, S., Kim, J.J., and Thompson, R.F. 1996. Hippocampal lesions impair contextual fear conditioning in two strains of mice. Behav. Neurosci. 110: 1117-1180.

Consolo, S., Baldi, G., Russi, G., Civenni, G., Bartfai, T., and Vezzani, A. 1994. Impulse flow dependency of galanin release in vivo in the rat ventral hippocampus. Proc. Natl. Acad. Sci. 91: 8047-8051.

Corcoran, K.A. and Maren, S. 2001. Hippocampal inactivation disrupts contextual retrieval of fear memory after extinction. J. Neurosci. 21: $1720-1726$

Crawley, J.N. and Paylor, R. 1997. A proposed test battery and constellations of specific behavioral paradigms to investigate the behavioral phenotypes of transgenic and knockout mice. Horm. Behav. 31: 197-211.

Crestani, F., Lorez, M., Baer, K., Essrich, C., Benke, D., Laurent, J.P., Belzung, C., Fritschy, J.M., Luscher, B., and Mohler, H. 1999. Decreased $\mathrm{GABA}_{\mathrm{A}}$-receptor clustering results in enhanced anxiety and a bias for threat cues. Nat. Neurosci. 2: 833-839.

Davis, M. and Whalen, P.J. 2001. The amygdala: Vigilance and emotion. Mol. Psychiatry 6: 13-34.

Fitzjohn, S.M., Bortolotto, Z.A., Palmer, M.J., Doherty, A.J., Ornstein, P.L., Schoepp, D.D., Kingston, A.E., Lodge, D., and Collingridge, G.L. 1998 The potent mGlu receptor antagonist LY341495 identifies roles for both cloned and novel mGlu receptors in hippocampal synaptic plasticity. Neuropharmacology 37: 1445-1458.

Fanselow, M.S. and Kim, J.J. 1994. Acquisition of contextual Pavlovian fear conditioning is blocked by application of an NMDA receptor antagonist D,L-2-amino-5-phosphonovaleric acid to the basolateral amygdala. Behav. Neurosci. 108: 210-212.

Gewirtz, J.C., McNish, K.A., and Davis, M. 2000. Is the hippocampus necessary for contextual fear conditioning? Behav. Brain Res. 110: 83-95.

Givens, B.S., Olton, D.S., and Crawley, J.N. 1992. Galanin in the medial septal area impairs working memory. Brain Res. 582: 71-77.

Gleason, T.C., Dreiling, J.L., and Crawley, J.N. 1999. Rat strain differences in response to galanin on the Morris water task. Neuropeptides 33: 265-270.

Hall, J., Thomas, K.L., and Everitt, B.J. 2001. Cellular imaging of zif268 expression in the hippocampus and amygdala during contextual and cued fear memory retrieval: Selective activation of hippocampal CA1 neurons during the recall of contextual memories. J. Neurosci. 21: 2186-2193.

Hökfelt, T., Millhorn, D., Seroogy, K., Tsuruo, Y., Ceccatelli, S., Lindh, B., Meister, B., Melander, T., Schalling, M., Bartfai, T., et al. 1987. Coexistence of peptides with classical neurotransmitters. Experientia 43: 768-780.

Holland, P.C. and Bouton, M.E. 1999. Hippocampus and context in classical conditioning. Curr. Opin. Neurobiol. 9: 195-202.

Holmes, A., Yang, R.J., and Crawley, J.N. 2002. Evaluation of an anxiety-related phenotype in galanin overexpressing transgenic mice. J. Mol. Neurosci. 18: 151-165.

Huerta, P.T., Sun, L.D., Wilson, M.A., and Tonegawa, S. 2000. Formation of temporal memory requires NMDA receptors within CA1 pyramidal neurons. Neuron 25: 473-480.

Iismaa, T.P. and Shine, J. 1999. Galanin and galanin receptors. Results Probl. Cell Differ. 26: 257-291.

Impey, S., Smith, D.M., Obrietan, K., Donahue, R., Wade, C., and Storm D.R. 1998. Stimulation of cAMP response element (CRE)-mediated transcription during contextual learning. Nat. Neurosci. 1: 595-601.

Karelson, E. and Langel, Ü. 1998. Galaninergic signaling and adenylate cyclase. Neuropeptides 32: 197-210.

Kim, J.J. and Fanselow, M.S. 1992. Modality-specific retrograde amnesia of fear. Science 256: 675-677.

Kinney, G.A., Emmerson, P.J., and Miller, R.J. 1998. Galanin receptor-mediated inhibition of glutamate release in the arcuate nucleus of the hypothalamus. J. Neurosci. 18: 3489-3500.

LeDoux, J.E., Cicchetti, P., Xagoraris, A., and Romanski, L.M. 1990. The lateral amygdaloid nucleus: Sensory interface of the amygdala in fear conditioning. J. Neurosci. 10: 1062-1069.

Logue, S.F., Paylor, R., and Wehner, J.M. 1997. Hippocampal lesions cause learning deficits in inbred mice in the Morris water maze and conditioned-fear task. Behav. Neurosci. 11: 104-113.

Malin, D.H., Novy, B.J., Lett-Brown, A.E., Plotner, R.E., May, B.T., Radulescu, S.J., Crothers, M.K., Osgood, L.D., and Lake, J.R. 1992. Galanin attenuates retention of one-trial reward learning. Life Sci. 50: 939-944.

Maren, S. 2000. Auditory fear conditioning increases CS-elicited spike firing in lateral amygdala neurons even after extensive overtraining. Eur. J. Neurosci. 12: 4047-4054.

Maren, S., Aharonov, G., and Fanselow, M.S. 1996a. Retrograde abolition of conditional fear after excitotoxic lesions in the basolateral amygdala of rats: Absence of a temporal gradient. Behav. Neurosci. 110(4): 718-726.

Maren, S., Aharonov, G., Stote, D.L., and Fanselow, M.S. 1996b. $\mathrm{N}$-methyl-D-aspartate receptors in the basolateral amygdala are required for both acquisition and expression of conditional fear in rats. Behav. Neurosci. 110: 1365-1374.

Mazarati, A.M., Hohmann, J.G., Bacon, A., Liu, H., Sankar, R., Steiner, R.A., Wynick, D., and Wasterlain, C.G. 2000. Modulation of hippocampal excitability and seizures by galanin. J. Neurosci. 20: 6276-6281.

McDonald, M.P. and Crawley, J.N. 1996. Galanin receptor antagonist M40

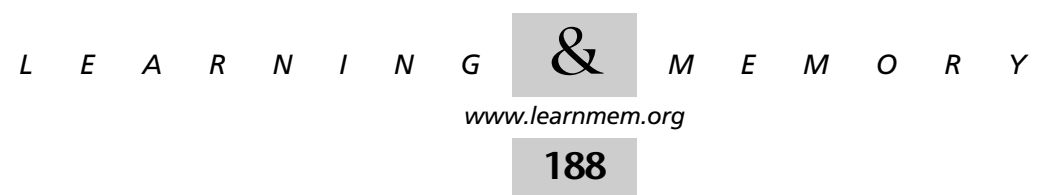


blocks galanin-induced choice accuracy deficits on a delayed-nonmatching-to-position task. Behav. Neurosci. 110: $1025-1032$.

1997. Galanin-acetylcholine interactions in rodent memory tasks and Alzheimer's disease. J. Psychiatry Neurosci. 22: 303-317.

McDonald, M.P., Wenk, G.L., and Crawley, J.N. 1997. Analysis of galanin and the galanin antagonist M40 on delayed non-matching-to-position performance in rats lesioned with the cholinergic immunotoxin 192 IgG-saporin. Behav. Neurosci. 111: 552-563.

McDonald, M.P., Gleason, T.C., Robinson, J.K., and Crawley, J.N. 1998. Galanin inhibits performance on rodent memory tasks. Ann. $N$ Y Acad. Sci. 863: 305-322.

McEchron, M.D., Bouwmeester, H., Tseng, W., Weiss, C., and Disterhoft, J.F. 1998. Hippocampectomy disrupts auditory trace fear conditioning and contextual fear conditioning in the rat. Hippocampus 8: 638-646.

McEchron, M.D., Tseng, W., and Disterhoft, J.F. 2000. Neurotoxic lesions of the dorsal hippocampus disrupt auditory-cued trace heart rate (fear) conditioning in rabbits. Hippocampus 10: 739-751.

McEchron, M.D., Weible, A.P., and Disterhoft, J.F. 2001. Aging and learning-specific changes in single-neuron activity in CA1 hippocampus during rabbit trace eyeblink conditioning. J. Neurophysiol. 86: $1839-1857$.

McNish, K.A., Gewirtz, J.C., and Davis, M. 1997. Evidence of contextual fear after lesions of the hippocampus: A disruption of freezing but not fear potentiated startle. J. Neurosci. 17: 9353-9360.

Moyer, J.R., Deyo, R.A., and Disterhoft, J.F. 1990. Hippocampectomy disrupts trace eye-blink conditioning in rabbits. Behav. Neurosci. 104: 243-252.

Mufson, E.J., Cochran, E., Benzing, W., and Kordower, J.H. 1993. Galaninergic innervation of the cholinergic vertical limb of the diagonal band (Ch2) and bed nucleus of the stria terminalis in aging, Alzheimer's disease and Down's syndrome. Dementia 4: 237-250.

Muschol, M. and Salzberg, B.M. 2000. Dependence of transient and residual calcium dynamics on action-potential patterning during neuropeptide secretion. J. Neurosci. 20: 6773-6780.

Nail-Boucherie, K., Dourmap, N., Jaffard, R., and Costentin, J. 2000. Contextual fear conditioning is associated with an increase of acetylcholine release in the hippocampus of rat. Brain Res. Cogn. Brain Res. 9: 193-197.

Ögren, S.O., Kehr, J., and Schött, P.A. 1996. Effects of ventral hippocampal galanin on spatial learning and on in vivo acetylcholine release in the rat. Neuroscience 75: 1127-1140.

Palazzi, E., Felinska, S., Zambelli, M., Fisone, G., Bartfai, T., and Consolo, S. 1991. Galanin reduces carbachol stimulation of phosphoinositide turnover in rat ventral hippocampus by lowering $\mathrm{Ca}^{2+}$ influx through voltage-sensitive $\mathrm{Ca}^{2+}$ channels. J. Neurochem. 56: 739-747.

Paxinos, G. and Watson, C. 1986. The rat brain in stereotaxic coordinates (second ed.). Academic Press, Orlando, FL.

Paylor, R., Tracy, R., Wehner, J., and Rudy, J.W. 1994. DBA/2 and C57BL/6 mice differ in contextual fear but not auditory fear conditioning. Behav. Neurosci. 108: 810-817.

Paylor, R., Nguyen, M., Crawley, J.N., Patrick, J., Beaudet, A., and Orr-Urtreger, A. 1998. $\alpha 7$ nicotinic receptor subunits are not necessary for hippocampal-dependent learning or sensorimotor gating: A behavioral characterization of Acra7-deficient mice. Learn. Mem. 5: 302-316.

Phillips, R.G. and LeDoux, J.E. 1992. Differential contribution of amygdala and hippocampus to cued and contextual fear conditioning. Behav. Neurosci. 106: 274-285.

-1994. Lesions of the dorsal hippocampal formation interfere with background but not foreground contextual fear conditioning. Learn. Mem. 1: 34-44.

Pontzer, N.J., Chandler, L.J., Stevens, B.R., and Crews, F.T. 1990. Receptors, phosphoinositol hydrolysis and plasticity of nerve cells. Prog. Brain Res. 86: 221-225.

Robinson, J.K. and Crawley, J.N. 1993a. Intraventricular galanin impairs delayed nonmatching-to-sample performance in rats. Behav. Neurosci. 107: $458-467$. 1993b. The role of galanin in cholinergically-mediated memory processes. Prog. Neuropsychopharmacol. Biol. Psychiatry 17: 71-85 . 1994. Analysis of anatomical sites at which galanin impairs delayed nonmatching to sample in rats. Behav. Neurosci. 108: 941-950.

Robinson, J.K., Zocchi, A., Pert, A., and Crawley, J.N. 1996. Galanin microinjected into the medial septum inhibits scopolamine-induced acetylcholine overflow in the rat ventral hippocampus. Brain. Res. 709: 81-87.

Rodrigues, S.M., Schafe, G.E., and LeDoux, J.E. 2001. Intra-amygdala blockade of the NR2B subunit of the NMDA receptor disrupts the acquisition but not the expression of fear conditioning. J. Neurosci. 21: 6889-6896.

Ryou, J.W., Cho, S.Y., and Kim, H.T. 2001. Lesions of the entorhinal cortex impair acquisition of hippocampal-dependent trace conditioning. Neurobiol. Learn. Mem. 75:121-127.

Schafe, G.E., Nader, K., Blair, H.T., and LeDoux, J.E. 2001. Memory consolidation of pavlovian fear conditioning: A cellular and molecular perspective. Trends Neurosci. 24: 540-546.

Schött, P.A., Bjelke, B., and Ögren, S.O. 1998a. Distribution and kinetics of galanin infused into the ventral hippocampus of the rat: Relationship to spatial learning. Neuroscience 83: 123-136.

Schött, P.A., Hökfelt, T., and Ögren, S.O. 2000. Galanin and spatial learning in the rat. Evidence for a differential role for galanin in subregions of the hippocampal formation. Neuropharmacology 39: 1386-1403.

. 1998b. Time-dependent effects of intrahippocampal galanin on spatial learning: Relationship to distribution and kinetics. Ann. NY Acad. Sci. 863: 454-456

Shandra, A.A., Mazarati, A.M., and Servetskii, K.L. 1994. Influence of the neuropeptide galanin on active avoidance in rats. Neurosci. Behav. Physiol. 24: 429-432.

Solomon, P.R., Vander-Schaaf, E.R., Thompson, R.F., and Weisz, D.J. 1986 Hippocampus and trace conditioning of the rabbit's classically conditioned nictitating membrane response. Behav. Neurosci. 100: $729-744$

Stefani, M.R. and Gold, P.E. 1998. Intra-septal injections of glucose and glibenclamide attenuate galanin-induced spontaneous alternation performance deficits in the rat. Brain Res. 813: 50-56.

Steiner, R.A., Hohmann, J.G., Holmes, A., Wrenn, C.C., Cadd, G., Jureus, A., Clifton, D.K., Luo, M., Gutshall, M., Ma, S.Y., et al. 2001. Galanin transgenic mice display cognitive and neurochemical deficits characteristic of Alzheimer's disease. Proc. Natl. Acad. Sci. 98: 4184-4189.

Sundstrom, E., Archer, T., Melander, T., and Hökfelt, T. 1988. Galanin impairs acquisition but not retrieval of spatial memory in rats studied in the Morris swim maze. Neurosci. Lett. 88: 331-335.

Sutherland, R.J. and McDonald, R.J. 1990. Hippocampus, amygdala, and memory deficits in rats. Behav. Brain. Res. 37(1): 57-79.

Ukai, M., Miura, M., and Kameyama, T. 1995. Effects of galanin on passive avoidance response, elevated plus-maze learning, and spontaneous alternation performance in mice. Peptides 16: 1283-1286.

Villacres, E.C., Wong, S.T., Chavkin, C., and Storm, D.R. 1998. Type I adenylyl cyclase mutant mice have impaired mossy fiber long-term potentiation. J. Neurosci. 18: 3186-3194.

Wang, H.Y., Wild, K.D., Shank, R.P., and Lee, D.H.S. 1999. Galanin inhibits acetylcholine release from rat cerebral cortex via a pertusis toxin-sensitive Gi protein. Neuropeptides 33: 197-205.

Wallenstein, G.V. and Vago, D.R. 2001. Intrahippocampal scopolamine impairs both acquisition and consolidation of contextual fear conditioning. Neurobiol. Learn. Mem. 75(3): 245-252.

Waters, S.M. and Krause, J.E. 2000. Distribution of galanin-1, -2 and -3 receptor messenger RNAs in central and peripheral rat tissues. Neuroscience 95: 265-271.

Wehner, J.M., Radcliffe, R.A., Rosmann, S.T., Christensen, S.C., Rasmussen, D.L., Fulker, D.W., and Wiles, M. 1997. Quantitative trait locus analysis of contextual fear conditioning in mice. Nat. Genet. 17: 331-334.

Weiss, C., Bouwmeester, H., Power, J.M., and Disterhoft, J.F. 1999.

\section{$\begin{array}{lllllllllllllll} & E & A & R & N & I & N & G & \mathcal{Q} & M & E & M & O & R & Y \\ \text { www.learnmem.org } & & \end{array}$}


Hippocampal lesions prevent trace eyeblink conditioning in the freely moving rat. Behav. Brain Res. 99: 123-132.

Weisskopf, M.G., Castillo, P.E., Zalutsky, R.A., and Nicoll, R.A. 1994.

Mediation of hippocampal mossy fiber long-term potentiation by cyclic AMP. Science 265: 1878-1882.

Wrenn, C.C. and Crawley, J.N. 2001. Pharmacological evidence supporting a role for galanin in cognition and affect. Prog. Neuropysychopharmacol. Biol. Psychiatry 25: 283-299.

Wu, Z.L., Thomas, S.A., Villacres, E.C., Xia, Z., Simmons, M.L., Chavkin, C., Palmiter, R.D., and Storm, D.R. 1995. Altered behavior and long-term potentiation in type I adenylyl cyclase mutant mice. Proc. Natl. Acad. Sci. 92: 220-224.
Xia, Z., Choi, E.J., Blazynski, C, and Storm, D.R. 1995. Do the calmodulin stimulated adenylyl cyclases play a role in neuroplasticity? Behav. Brain Sci. 18: 429-440.

Young, E.A., Owen, E.H., Meiri, K.F., and Wehner, J.M. 2000. Alterations in hippocampal GAP-43 phosphorylation and protein level following contextual fear conditioning. Brain Res. 860: 95-103.

Zini, S., Roisin, M.P., Langel, Ü., Bartfai, T., and Ben-Ari, Y. 1993. Galanin reduces release of endogenous excitatory amino acids in the rat hippocampus. Eur. J. Pharmacol. 245: 1-7.

Received April 22, 2002; accepted in revised form June 21, 2002.

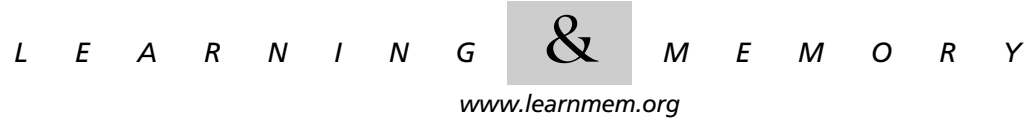




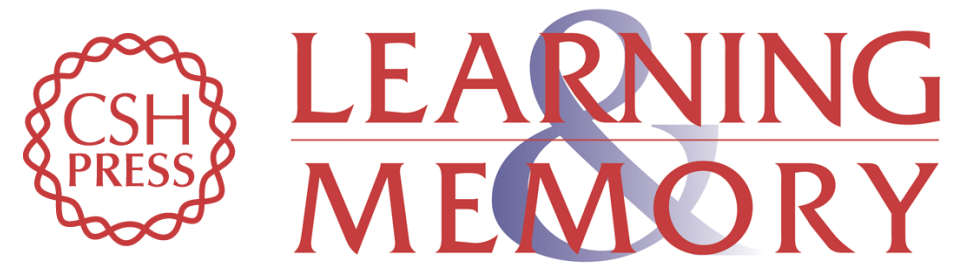

\section{Deficits in Trace Cued Fear Conditioning in Galanin-Treated Rats and Galanin-Overexpressing Transgenic Mice}

Jefferson W. Kinney, Grzegorz Starosta, Andrew Holmes, et al.

Learn. Mem. 2002, 9:

Access the most recent version at doi:10.1101/m.49502

References This article cites 85 articles, 18 of which can be accessed free at:

http://learnmem.cshlp.org/content/9/4/178.full.htmI\#ref-list-1

License

Email Alerting Receive free email alerts when new articles cite this article - sign up in the box at the Service top right corner of the article or click here. 